This is a preprint version of the article:

Van Daele, S., \& Vander Beken, T. (2010). Exploring itinerant crime groups. European

Journal on Criminal Policy and Research 16(1), 1-13, doi: 10.1007/s10610-009-9114-y

\begin{abstract}
:
Starting a decade ago, property crimes by Eastern European crime gangs have gained attention of Belgian law enforcement agencies. Due to the mobile nature of these groups, the term 'itinerant crime groups' has been used. The aim of this article is to explore what is incorporated in this term. By analyzing 27 case files, a large degree of variation is revealed. Groups differ in size, organizational structure, offender characteristics, the crimes in which they are involved and the methods they use. Following these features, two main types of itinerant crime groups can be distinguished, each with their own diversity. As such, the observed heterogeneity is larger than we might suspect by looking at the policy definition of the phenomenon.
\end{abstract}

\title{
Keywords:
}

Itinerant crime groups; organized crime; property crime; Eastern European crime; case file analysis 


\section{Exploring itinerant crime groups}

Stijn Van Daele \& Tom Vander Beken

\section{Itinerant crime groups defined}

Organised property crime and, in particular, so-called itinerant crime groups have received considerable attention in Belgium since the start of the twenty-first century. The phenomenon was first observed in the late 1990s by the Belgian police force (De Ruyver, 2006a). On the basis of a limited number of case files (Dupuis, 2004), the authorities believed they had discovered a new phenomenon. After half a decade of fine-tuning, the phenomenon was defined and recorded in Belgian criminal policy, in the so-called Kadernota Integrale Veiligheid (Belgian Ministerial College, 2004) . Policies concerning these crime groups, and how to define their members, were updated by the government in a revised action plan $(22 / 03 / 2007)$, when "itinerant crime groups" were identified as having the following characteristics:

- an association of criminals;

- systematically committing residential burglaries or burglaries of commercial properties, including ram raids, cargo thefts, metal thefts or thefts of construction vehicles and materials;

- originating mainly from the former Eastern Bloc;

- operating or directed from abroad or from large conurbations in Belgium;

- committing a significant number of crimes over a large area; and

- possibly using minors to commit crimes.

Between 60 and 80 such groups have been identified each year in Belgium since 2004 (De Raedt, 2006b). The size of these groups changes, indicating that their structure is flexible, and the organisations have become smaller (De Raedt, 2006b: 41). An overview of the case files reveals a large variety of groups. Some only comprise around five offenders, while others have more than 70 members. The number of offences committed range from a couple of dozens to, exceptionally, more than 1,000 crimes.

Organised property crime by these groups is raising concerns not only in Belgium, but also in some of its neighbouring countries, under a variety of names. In the Netherlands, France and Germany they are labelled, respectively, "mobile banditism" (Huisman and Van der Laan, 2005; Van der Laan and Weenink, 2005) "itinerant crime" (Marro, 2002) and "Eastern European criminal groups" (Dortans, 2007). In each of these countries a defining element of 
these groups is that they systematically commit property offences. However, other noncriminal characteristics have also been identified.

The first is their nationality. The groups that fall under this definition are of Eastern European origin. This creates the risk of targeting these groups disproportionately and, therefore, the definition is linked to a sensitive debate, namely that of ethnicity and crime. The second is a high degree of mobility; this is often reflected in the terms used to describe them, and it is widely accepted that these groups travel long distances to commit their crimes. While for some groups such itinerancy is a way of life, others may travel because they function as what Canter called "criminal commuters" (Canter and Larkin, 1993). Yet, linking itinerancy with criminality is controversial as well, because people with higher mobility tend already to suffer from the preconception that they are criminals (James, 2007). Both features - mobility and nationality - are encountered in law enforcement perception, but also in empirical data (Van Daele, 2008; Van Daele et al., 2008).

\section{Case file diversity}

A first question arising when starting our analysis was to determine which case files were suitable. Participation in itinerant crime groups is not considered a qualified crime in Belgium. One cannot be punished more severely when being part of such a group. The result is that enforcement agencies try to charge these groups with being criminal organisations. However, because these organisations receive particular attention within law enforcement agencies, studying only those defined as criminal organisations would cause a loss of information. We therefore opted for another approach. Contacts were made with judicial police forces in five districts with various features: geographic location, size, degrees of urbanisation and whether the district mainly functions as target area or more as a starting point. We explained the focus of our research and asked for a variation in the case files, after which the persons involved supplied us with a number of case files, which they considered as interesting for our research.

The result is a data set of 27 case files of so-called "itinerant crime groups". Because the focus in case selection was put on variation and not on representativeness, only qualitative conclusions can be drawn and we will not make quantitative statements. However, even without the possibility to quantify the results, relevant information can be provided. One should not forget that the phenomenon is quite new and, except for a couple of valuable police studies (see for example De Cock, 2007; De Ruyver, 2006b; Dupuis, 2004; Huisman and Van 
der Laan, 2005; Paulussen, 2007; Stichting Maatschappij Veiligheid en Politie, 2006; Van der Laan and Weenink, 2005) academic interest for the phenomenon is new and rather limited (see Ponsaers, 2004; Van Daele, 2008; Van Daele et al., 2008 for some existing papers).

\section{Levels of organisation and structure}

Due to the selection mechanism used in our analysis, a large variety of crime groups is captured. One of the issues in which this is easily observed is the organisational structure of these groups. The Belgian annual report on organised crime (Dienst voor het Strafrechtelijk Beleid, 2005: 32-34, 2007: 62-64) distinguished four levels of organisation, ranging from highly structured and internationally active to opportunistic, temporary active groups. The highly organised groups can be dealt with as criminal organisations, but for the small groups, this is less likely. Our analysis found both highly structured as barely structured groups, including those in between.

At one extreme, we studied a highly structured organisation of Georgian origin. The group was known mainly for the organisation of vehicle thefts and contained various organisational levels. There was a leader, residing in Belgium and living in great luxury. He had some people he trusted and worked closely together with. Other people were situated a bit lower in the hierarchy: couriers, a forger and several people involved in the maintenance of the "obchak" - a word used to describe the system of social and financial security within Russianlike criminal organisations (Lyman and Potter, 1997). At the lowest level were the executioners of the crimes. They had a much less luxurious lifestyle and were sometimes 'transferred' from this gang to other gangs abroad.

At the other extreme, we found a group, coming over to Belgium for a short period. Offenders stayed with a Belgian couple and operated in small groups. There was no real structure or leadership and the offenders lived in poor circumstances.

Structural features of most groups are situated somewhere between the two cases described above. However, we chose not to further divide into categories. Structural features are to be viewed as a continuum: we established the two extremes and observed various types in between. Therefore, any further division would be artificial and influenced by personal choice and interpretation. Moreover, defining the structural typology of a group is not always straightforward. Depending on the attention paid by investigating officers, groups can seem to be much more or less structured. We encountered one group which was loosely structured according to the case file and our police contact. However, other features such as violence, 
number of offences and group size resemble that of more structured groups. Instead of further dividing the groups, we see more added value in linking group structure to other features like offender characteristics, crime types, mobility, strategies and the criminal fence.

Group sizes differ as well. Group size is not always linked to organisational levels. Of course, highly structured groups will have more than two or three offenders. In general, hierarchically structured groups are larger. Yet, some groups consist of several offenders - 15 for example outside a clearly defined structure. In these cases, opportunistic and temporary cooperation leads to more offenders being involved.

\section{Offender characteristics}

The vast majority of offenders are men. They are involved in criminal operations and in case of hierarchy, men have the highest functions. This does not mean that no women are involved. In about half of the groups studied, some women play a role within the organization as well. Most of them are partners of one of the male offenders. They are active in supporting activities like providing accommodation, logistic support and sometimes even fencing. It is not always clear to what extent their contributions are essential to the group activities. When residing with their respective partners, it is not astonishing that their cell phone numbers are encountered during the investigation. Thus, their activities, be it essential or not, are likely to be revealed as well. Despite the generally limited involvement of women, two cases reveal otherwise. In these two cases, women are active in the group's criminal operations and not only provide support.

Most offenders are rather young or middle-aged. Several groups contain offenders born in the 1950 s or even the 1940s. A slightly larger proportion is born in the 1960s. The vast majority of nearly all offender groups are perpetrators born in the 1970s and the first half of the 1980s. Most offenders are in their twenties or thirties. Several groups contain older offenders as well. Most offenders are experienced too. They often have a criminal record, either in their home country, Belgium or even a third country. The crimes they have been known for mostly include property crimes, but also violence - whether or not while committing property crimes - fraud, forgery and sometimes even drug crimes. While most offenders are adults and often experienced, this is not always the case. Two groups use minors for criminal purposes. Remarkable is the fact that these are the same groups involving women for crime and not only for supporting activities. They each comprise several families and within these families, crime is a common activity, not only committed by men, but also by other family members such as 
women and children, so it appears. This does not mean that the methods are the same: women and children mostly commit their crimes by using deception or tricks. They sometimes try to gain access to target premises by pretending to sell certain items. Other methods include ringing the doorbell to see whether there is any presence. If someone opens the door, they ask for simple things - the road to a nearby village for example - and if not, they burgle the house.

As mentioned, some groups consist of family members, which immediately explains their origin and the relationship between the offenders. Yet, this does not mean that all offenders within these groups are family. There are mostly a number of families, surrounded by other individuals. This results in a mix between families and other. We believe it is therefore better to speak of clan-wise structure instead of family structure. This clan structure is observed in most gypsy groups. Some of them have come to Western Europe more recently, while others have stayed here for longer periods and have mixed with indigenous groups. While the first are active throughout the country, the latter are mostly active in the border regions.

Not all groups are characterized by a clan structure. Within some groups, the members mention no previous relationship at all. Their cases show no evidence of other relationships than having come to Belgium separately, in search for a better life, and having met each other by coincidence. In search for work, they made contact with people in the same situation and in this way, got involved into crime. Yet, this is not the case for all groups. In several cases, offenders originated from the same region or even the same town. Although it is not always explicitly mentioned in the files - being no investigation priority - it is quite likely that they have known each other beforehand.

Members of other groups seem to have no known personal relationship, but are accepted in a certain group because they are part of the broader structure within which the group operates. This is particularly observed in highly structured groups.

A final offender characteristic is nationality. It is often mentioned that these groups are from Eastern European origin. That does not mean that only Eastern European offenders systematically commit property crimes. Some groups contain a mix of nationalities, within or outside Eastern Europe. It mostly occurred that there is one dominant nationality, surrounded and supported by several figures of other nationalities. The encountered main nationalities are Rumanian - with or without Moldovan - and former Yugoslavian (each 8 cases), Albanian and Georgian (each 3 cases) and Polish (1 case). Some districts consider other nationalities as well. Two groups are mainly French, one group Dutch and one Belgian. Border district police forces have observed groups with similar methods but not of Eastern European origin. Thus, 
they do not consider Eastern European nationality as necessary condition for itinerant crime groups. Several groups have no homogenous composition. Surrounding people have nationalities ranging from all sorts of Eastern European nationalities (those already mentioned above, but also offenders originating from Ukraine, Bulgaria, Slovenia, Russia, Czech Republic, Belarus) to Western European offenders (French, Dutch, Belgian and naturalized Belgian) and even Southern European (Italian) and Northern African (Moroccan) offenders. Observing only offender features, it already appears that "itinerant crime group" is a heterogeneous concept. The majority of offenders are men, young adults or middle-aged, of Eastern European nationalities. However, they are supported by older offenders, women and offenders from other nationalities. In some cases, other offenders' activities extend support: in some gypsy groups, women play an active role in criminal behaviour, and so do even children. In other groups, involved in border region crime, Eastern European nationalities are not as dominant as elsewhere.

\section{Crime types}

Itinerant crime groups are mainly active in the area of property crimes. The number of offences ranges from 4 to more than 400 . These are only estimates, as it is not always possible to prove the involvement of a group into a certain crime. Therefore, enforcement authorities sometimes choose to focus more on investigating and proving a rather limited number of crimes than bringing all highly likely group activities in picture. There is no clear correlation between the number of crimes committed and the duration of activity: some groups have been active for more than two years and have 'only' committed about 80 property crimes, others have succeeded in committing probably up to 400 crimes just in eight months, of which they were really active for less than 5 . There is some link between group structure and number of crimes. Yet, this should not be overrated. Well-structured groups particularly choosing their targets and specialized in certain crimes will very likely commit less crimes than small groups committing random burglaries.

Home burglaries and car thefts occur most often and are committed by almost any group. Other crimes are committed by some groups. An alternative to car thefts is stealing anything inside the vehicle: electronic devices but also work material that is locked in vans. Commercial burglaries require more knowledge and are committed less often. Nevertheless, a couple of groups is specialized in it, but they mostly commit less crimes within a certain period. The same counts for metal thefts and thefts of documents: it is no activity in which 
most groups engage, but the domain of a few groups. Even more specialization is required for skimming. Thus, the latter has only been observed in a minority of groups.

Ram raiding is the final property crime type encountered in our case file analysis. Although few groups tend to commit a limited amount of ram raids, two groups make it their main criminal activity. Both of them belong to the "border region crime" type described above: the offenders are not illegally residing Eastern Europeans, but Western European, operating at both sides of the border.

It is typical for these groups that they are active in the area of 'ordinary' property crimes. However, one police officers told us that this had more to do with the police structure in Belgium - each police department being divided according crime types they investigate - than with the activities of these groups. Because the cases were provided by the property crime departments of the police, we had only limited information on other crimes than property offences. Yet, there was often information on other crimes these groups were involved in. We did not consider criminal fence as a separate crime type, because it is a consequence of committed property crimes. Still, ten case files dealt with multi-criminal groups. This does not mean that the rest is not involved in other crimes than property offences. It only means that there was no such information obtained from the case file.

Five groups have been known for forging identification papers. By using fake identity papers, offenders succeed in moving more freely into and throughout Europe. In this way, the use of false papers is not completely strange. Other crimes have different degrees of seriousness ranging from prohibited use of weapons and use of violence (one case each) to severe crimes such as manslaughter (three cases) and more internationally oriented crimes like trafficking in human beings (one case) and drug trafficking (seven cases). Multi-criminality is linked to structural features. Two multi-crime groups have only limited structures. However, their multi-criminal behaviour is limited to forgery, prohibited use of weapons and drug-related activities. Most groups known for multi-criminal activity, however, are well-structured, have international links and/or operate on an international level.

Itinerant crime groups are known for systematically committing property crimes. These range from rather easily approachable examples, such as burglary and car theft, to more specialized offences like metal theft, commercial burglary, theft of documents, skimming and ram raiding, the latter being mostly committed by border region crime groups. However, the criminal repertory of itinerant crime groups does not stop there: particularly the highly structured groups are engaged in trafficking in drug trafficking, trafficking in human beings, prohibited use of weapons and even violence and manslaughter. 


\section{Mobility}

Itinerant crime groups engage mainly in systematically committing property crimes, but also in other aspects of the criminal perspective. True, they are organized, and some are more than others, but engagement in property crimes does not make them completely different from other criminal gangs or organizations. Spapens and Fijnaut (2005: 82) distinguish four offender types in their study on organized burglary. Next to itinerant crime groups - or mobile gangs - as they call them, professional thieves may also operate in groups and/or work in organized structures. The same counts for car theft and smuggling of stolen vehicles, another example of property crimes executed by criminal groups (Bruinsma and Bernasco, 2004: 86; Spapens and Fijnaut, 2005: 98). Then what is it that makes these itinerant crime groups this special? Although choice of words varies to describe these groups, mobility is a recurrent issue. Question hereby, however, is how to understand this mobility. Is it a part of their lifestyle, are they travellers? In that case, one should avoid to generalize, as these people have to deal with presumptions as being criminal already (James, 2007). Or are they just mobile in their criminal behaviour, travelling further when committing crimes but not travelling as a way of life at all? The latter would mean they conflict with reigning criminological theories such as distance decay theory (see for example Rattner and Portnov, 2007; Rengert et al., 1999; Van Koppen and De Keijser, 1997). Ponsaers (2004) opted for the first option, stating that criminal behaviour of these groups challenges distance decay theory mainly because these offenders have no fixed residences, making it hard to assess their offending patterns.

Our case file analysis showed that most offenders stay in Belgium illegally and only for rather short periods. This seems to confirm the travelling lifestyle hypothesis. However, looking at the individual offender is too limited and group offending cannot be explained by making the sum of all perpetrators individually (Tillyer and Kennedy, 2008: 81). From a group point of view, itinerant lifestyles account for only a part of these groups. Journey-to-crime of offender groups may cause problems, because distance should be measured from two points and mostly, operations will be located nearby the anchor point of one of the offenders (Bernasco, 2006: 147). For our subject groups, this is mostly no problem, as the starting point for one offender is the same or very nearby as for the others. In rare cases where more than one starting point was encountered, police investigations managed to clearly distinguish the relevant starting point. 
Study of the anchor points of itinerant crime groups learns us two things. From a theoretical perspective, larger travelled distances cannot be attributed to wrong registration of the anchor points. These offenders are mobile after all, particularly in their criminal behaviour. Therefore, there is a need for further analysis to explain this high level of mobility. From a practical perspective, crime trips and starting points thereof can be assessed. This is quite important, as it creates opportunities to investigate and capture the totality of a group, not only the people committing the crimes, but other actors being involved as well. Crime trips often started in similar, so-called vulnerable, neighbourhoods and sometimes even the same temporary residences returned. One of the contacted police officers mentioned this as being quite common, particularly in cases where third parties provide these residences.

\section{Criminal fence}

Itinerant crime groups travel large distances when committing crimes and this cannot be attributed to lack of fixed residences. Anchor point analysis shows that most groups have one or more offenders living in Belgium and/or connections with locally embedded people. This does not necessarily mean that all operations occur on a local or national level. In order to further assess mobility patterns, the relationships and fencing networks have been studied. These are not always investigation priorities and may therefore remain unclear in some cases. Nevertheless, some relevant information could be obtained. Lu (2003), in a study on vehicle theft, found that mobility patterns after crimes may as well reflect distance decay and be rather similar to traditional journey-to-crime patterns. The criminal fence can be an important factor in crime, because the relationship between the criminal receiver and the thief is essential for both parties. Nevertheless, attention for the criminal fence is rather limited. Sutton (1998) distinguishes five types of fencing markets, ranging from commercial sales to hawking i.e. directly selling to consumers in clubs, pubs,...

Studies showed criminal receivers not always being professional receivers/criminals (Kruize, 2007: 53-56) and fencing often occurring through informal ways (Kleemans, 1996: 71). Concerning the itinerant crime groups, some professional receivers were pictured. One case involved a fence dealing with expensive jewellery. In some other cases the fence took place in one or more pawnshops and for metal thefts, stolen goods are often sold to scrap dealers. This does not mean that these receivers are always aware of the criminal nature of the goods. Yet, while some cases involve professional receivers, most fencing activities take place through informal networks. These can be situated on a local level or abroad. Local fencing takes place 
through locally embedded persons or within the informal networks of the group (for example gypsy communities). In general, these groups steal easily disposable goods like jewellery, money and small electronics. One case involves a group being active in thefts of working tools. Buyers were then sought through a number of phone calls. In other cases, goods and vehicles were sold on second hand markets.

Most groups find ways to sell their stolen goods. Nevertheless, alternatives exist. First, some groups steal goods they do not have to sell, because they need not be sold. This can be the case for money, but also for small amounts of jewellery and small electronics. Typical for some of these groups, however, is that they steal consumables: food, drinks, cigarettes,... This is often the case for small, loosely structured groups and traveller clans (both Eastern European as indigenous). A second alternative is international fencing. A majority of the groups in our sample let the people in their home country benefit from their criminal behaviour. This includes transporting stolen goods (mostly by car) and stolen vehicles (mostly driven, rarely by boat), but also sending money home, often through money transfer companies. One should not forget that, although most groups have anchor points in Western Europe, the group members change. Thus, their family and sometimes even the centre of their own life, may still be situated in their home country. In this way, crime can be seen as an investment for a better life, both for them - whether or not they stay here for a longer time and for their family (see also Segaert, 2006: 30). Rarely, criminal earnings are invested in further criminal activity.

Fencing activities for itinerant crime groups vary from own use and local activities through international fencing and letting the family benefit from the earnings. This variation offers opportunities to find out to what extent groups and group members still have connections with their home country and their degree of embedment in local society.

\section{Risk management}

As not all itinerant crime groups have a similar structure or composition, and they are active in various domains of property crimes and beyond, it comes as no surprise that methods and strategies differ as well. Part of this difference is related to crime type: commercial burglaries require more sophisticated ore quicker methods (due to alarms) than most home burglaries, cars can be stolen either on the street by force or by stealing the keys inside the house first, the latter case being called 'garage theft', ram raids require cars and some degree of violence,... However, other strategies may differ as well. Offenders, just as their possible 
victims, engage in some form of risk management, trying to maximize their chances of success.

One of these strategies is preparation and planning. This occurs mostly in case of more advanced forms of crime and/or specific targets (De Cock, 2006: 47, 2007). After the decision to commit burglaries has been taken, there is often little or no further preparation. Bennett and Wright (1984: 45-46) called this typology 'the search'. In their sample, nearly half of the offenders belong to this type. Other authors observed this typology as well, also in Belgium (see Verwee et al., 2007: 104-106). Repeat victimization occurs regularly. Six groups hit the same targets during their operations. Another group does not really target the same premises, but always targets the same type of vacation houses, with exactly the same arrangement. For burglaries, repeat victimization is not a exclusive operation method of these groups. On the contrary, re-victimization is quite common (Nee and Meenaghan, 2006: 946). Itinerant crime groups follow no totally different preparation scheme than other burglars either. What is rather typical, however, is that they often operate in series.

One possible explanation for this serial behaviour is that they do not fear police action (De Cock, 2007). They do fear imprisonment, however, particularly if it were in their home country (De Cock, 2006). As a consequence, various risk reducing measures have been observed. One often encountered strategy is reconnaissance activity, noticed in 18 out of 27 case files. The extent of reconnaissance varies. Most of them were performed shortly - one or a couple of days - before the crimes. Concerning residential burglaries, reconnaissance was, if present, often limited to a rather short exploration of the area, sometimes even by other people than those burgling. For commercial burglaries, this was more systematic: more information was obtained and targets were picked more carefully. One group had inside information on their targets and another had a map with all companies of their target type in Belgium and France.

Using strategies such as repeat victimization, planning, reconnaissance and mapping, these offender groups become familiar with their target areas and become aware of the features of their region of operation. Brantingham and Brantingham (1981) defined the awareness space as the area of which offenders have knowledge. The gaining of this knowledge is based on both criminal and innocent activities (Brantingham and Brantingham, 1981: 35). 'Innocent' activities can include work, school, shopping and leisure. Despite some exceptions, no information on 'innocent creation of awareness space' is known for these groups. Repeat victimization may be an explanation for further criminal activity, but it does not explain the initial criminal behaviour within a certain region. Because crime trips into unknown 
territories are relatively rare (Palmer et al., 2002: 12; Van der Kemp and Van Koppen, 2007: 353), further research on the awareness space of these criminals is needed.

Next to the creation of awareness space and increasing knowledge on the target area, other risk management measures are encountered as well. Most groups use what we may call 'silent' strategies to avoid arrests: they reduce traceability by using phone cells, regularly changing SIM-cards and cell phones, use codes in conversation, use false identities and ID papers, destroy evidence, only commit crimes when the residents are absent (this is not new see also Bennett and Wright, 1984: 94; Kleemans, 1996: 53-54), minimize telephone contacts during the crimes, flee or temporarily stop criminal activity when they scent danger, use the way of least resistance and mislead potential victims. Violence towards victims is often not used or only to a limited extent, while internal violence is slightly more common. However, not all of them apply only silent/discrete strategies to reduce risks. One group committed one burglary in advance, in order to find out how long it would take the police authorities to arrive. Other groups block to road for police cars, act blatant in their criminal operations and threaten with or use violence against victims and/or police when pursued.

\section{Towards a typology of itinerant crime groups}

Various features have been attributed to itinerant crime groups. A qualitative case file analysis revealed a lot of variation, in organizational level, but also in offender characteristics, crime type, mobility, the criminal fence and risk management. In general, two main group types can be distinguished. On the one hand, we find the gypsy type groups, on the other the crime gangs. For each type, two extremes have been noticed. Thus, 4 extremes are observed, each with their own particular features (see table 1). Although we have divided the itinerant crime groups into two main group types, this does not mean that there can be no mixed groups at all, but most of them will incline towards one or the other. 
Table 1: Typology of Itinerant Crime Groups

\begin{tabular}{|c|c||c|c|}
\hline \multicolumn{3}{|c|}{ "Itinerant Crime Groups" } \\
\hline \multicolumn{2}{|c|}{$\begin{array}{c}\text { Criminal Communities: } \\
\text { Clan wise structure }\end{array}$} & Wangs: \\
Working together \\
\hline Ranging from: & to: & To: \\
\hline Border region groups & $\begin{array}{c}\text { Flexible gypsy from: } \\
\text { groups }\end{array}$ & Fortune-hunters & Professional groups \\
\hline
\end{tabular}

The first main type can best be describes as criminal communities. They have a clan wise structure and are characterized by a number of kinship relations: one or several families live together and know of each other's activities. They often form a part of the gypsy community, but it is important not to put them all in the same box: observed criminal activities should not lead to stigmatization of the whole gypsy community. Two subtypes have been noticed, each with their own specialization.

At the one extreme of the criminal communities we found the border region crime groups: small clans staying mostly in trailer camps in the border regions. These groups stay mostly within the same region. They are active in various types of property crimes, particularly including vehicle thefts and ram raids at both sides of the border. Their targets have often been repeatedly victimized and they make few efforts to stay unnoticed. When confronted with police, they flee, create distractions and try to eliminate their traces, for example by leaving/burning their cars and blocking the road for police vehicles.

At the other extreme, we found flexible gypsy groups. Some members stay within the same region, be it in trailer camps or in houses. These groups have international connections with other clans. This is observed in group membership (members being connected to several groups in various countries) and fencing activities (international fencing, making it difficult to trace the nature of certain goods). Flexibility is also observed in criminal behaviour: some of the groups are multi-criminal in a way that they do not only commit property crimes. Yet, there is more flexibility than this: whereas in other group types, crimes are almost exclusively committed by adult men, this is not the case here. Children and women are also sent out for stealing. Typical is that they avoid conflict, both with victims and with other actors such as witnesses or police. In order to do so, they use tricks and deception to gain access to houses and to rob people. Although cases are known of internal violence and conflicts, this is mostly 
not translated into violence towards victims, another example of their conflict-evading behaviour.

The second main type consists of crime gangs, not crime clans. Although some relatives may be encountered within a group, this is rather exceptional. These group members organize themselves not as a part of their lifestyle, but as part of their criminal behaviour. The reason for these groups to exist lies within their criminal actions. Again, two subtypes are observed, but here there is more of a continuum. The gypsy groups were both characterized by their own way of specialization. Within the crime gangs however, one type is clearly characterized by higher levels of organization, professionalism and specialization than the other.

At the low extreme we find groups of fortune-hunters. They have come over to Western Europe to create a better life back home. Some of them even did not know where to stay when they started their trip, some of them had a connection with someone here who was to provide temporary residences. They are loosely structured and, although they may have a criminal record back home, they are not specialized in particular crime types. Typical for this group type is the involvement in burglaries and car thefts, crimes for which only limited skills are required. From the group perspective, we often observe fixed anchor points in Belgium. From the perspective of the individual offender, however, temporariness is the key concept. Offenders of this fortune-hunter group type come over for short periods, regularly together with people they know, and return to their home country afterwards. They do not try to build up a life in Western Europe. This is reflected in the criminal earnings, which are transported to their home country. Relations with their homeland are vital and in several case files, offenders called their relatives using the phone in the house they burgled. Thus, there is an international perspective linked to these groups, but it is mostly bilateral: only the country of origin and the country they operate are involved. This, amongst other things, distinguishes them from the second type of crime gangs.

At the high end, we encounter highly professional and skilled groups. They engage in all sorts of criminal behaviour. Next to property crimes, links have been found with drugs smuggling, trafficking in human beings, violence,... the heart of the structure lies not in the country of origin but in Western Europe. These groups have international connections as well. However, the connections here are multilateral and also linked to other Western European countries. Group members are changing, not because they return back home but because they are transferred to other groups. The Western European focus of these groups is also translated in the criminal fence. Goods are more likely to be sold in the West or transported via detours to the East, there is more investment in other criminal activities and items such as real estate, art 
and luxury goods. The reason they are brought under the heading "itinerant crime groups" is mainly because of their Eastern European origin, not because of their itinerant/flexible behaviour.

\section{Back to the definition}

The Belgian definition of itinerant crime groups mentions a number of relevant issues to distinguish these groups. They are groups, originating mainly from the Eastern Bloc and committing a variation of property crimes. Other important aspects are their mobility, the fact that they operate from abroad or from the large Belgian conurbations, and the possible use of minors. As the police forces indicate themselves (De Raedt, 2006a: 23), this definition is based on empirical observations starting from the 1990s. Our case file analysis reveals that a high degree of variation is captured under the notion of "itinerant crime groups". Four main group types of itinerant crime groups have been observed. Linking the definition to the group types we encountered in our case file analysis, a number of questions are raised.

First, although border region crime groups are considered itinerant crime groups, one can ask whether this is truly the case. They are groups and are involved in property crimes. However, their operations are mainly limited to the border regions and as such, they are less mobile than the other types. They are also often Dutch or French instead of Eastern European. As mobility and nationality appear to be two important issues in the definition, one could wonder whether these border region crime clans are indeed itinerant crime groups.

Second, the definition mentions the possible use of minors. However, this has only been encountered in one type of groups. Although this aspect can be interesting to study, it is not a generally encountered feature of these groups. Therefore, including it in the definition may be confusing rather than clarifying.

Third, most groups - and certainly the large ones - are charged with being criminal organisations, and one could wonder whether there is an added value in another definition. Moreover, the emphasis in other countries is not always the same. In Germany (see for example Dortans, 2007), mobility is not really considered a determining issue, while in the Netherlands, the use of hit-and-run techniques is mentioned (Van der Laan and Weenink, 2005: 13), indicating short-term mobility and a very short stay in the target country - days instead of months. Thus, the phenomenon is addressed differently in the countries where it is observed, making comparisons and law enforcement cooperation more difficult. 


\section{Conclusion}

Itinerant crime groups have increasingly gained attention by police forces in Western Europe, in this case Belgium. Policy makers have tried to put the phenomenon of Eastern European criminal gangs committing property crimes in a definition, but the scope of this definition is rather broad and not exhaustive, so it appears. A case file analysis of 27 groups shows large degrees of variation. There is heterogeneity in levels of organization, but also in offender characteristics, crime types, fencing, risk management and not to the least extent mobility. Because of these variations a further division into subtypes seemed appropriate. Criminal communities cannot be easily compared with Eastern European crime gangs and even within each type, the case files reveal large degrees of heterogeneity. There is one term used to describe these offender groups: "itinerant crime groups". However, our case file analysis shows that 'groups' are herewith interpreted in various ways, ranging from flexible, loosely structured to highly professional, 'crime' can be more than just property crimes and 'itinerant' is by no means straightforward, as many groups have fixed bases or even residences in Western Europe. 


\section{Acknowledgements}

The authors would like to thank the Belgian Federal Police and its officials who took the time to talk to us, helped us find our way through the case files and revealed additional information on the difficulties they encountered.

\section{References}

Actieplan van de Regering, FOD Justitie, FOD Kanselarij van de Eerste Minister, and FOD Binnenlandse zaken (22/03/2007). De aanpak van de rondtrekkende dadergroeperingen: een actualisatie: Federale Politie.

Belgian Ministerial College (2004). Kadernota Integrale Veiligheid.

Bennett, T., and Wright, R. (1984). Burglars on burglary. Aldershot: Gower.

Bernasco, W. (2006). Co-offending and the choice of target areas in burglary. Journal of Investigative Psychology and Offender Profiling, 3(3), 139-155.

Brantingham, P., and Brantingham, P. (1981). Notes on the geometry of crime. In P. Brantingham and P. Brantingham (Eds.), Environmental criminology (pp. 27-54). Beverly Hills: Sage.

Bruinsma, G., and Bernasco, W. (2004). Criminal groups and transnational markets: a more detailed examination on the basis of social network theory. Crime Law and Social Change, 41(1), 79-94.

Canter, D., and Larkin, P. (1993). The environmental range of serial rapists. Journal of Environmental Psychology, 13(1), 63-69.

De Cock, K. (2006). De rondtrekkende daders aan het woord. In B. De Ruyver (Ed.), Rondtrekkende daders: grensoverschrijdend beleid (pp. 45-51). Brussels: Politeia.

De Cock, K. (2007). Rondtrekkende daders: wie zijn ze, wat drijft hen? PolitiejournaalPolitieofficier(2), 6-9.

De Raedt, E. (2006a). Beeldvorming inzake dievenbendes: let's have insight to see inside. In B. De Ruyver (Ed.), Rondtrekkende dadergroepen: grensoverschrijdend beleid (pp. 23-26). Brussels: Politeia.

De Raedt, E. (2006b). Rondtrekkende daders: dynamiek in de criminele markt. In B. De Ruyver (Ed.), Rondtrekkende dadergroepen: grensoverschrijdend beleid (pp. 39-44). Brussels: Politeia.

De Ruyver, B. (2006a). Ten geleide. In B. De Ruyver (Ed.), Rondtrekkende dadergroepen: Grensoverschrijdend beleid (pp. 5-8). Brussel: Politeia.

De Ruyver, B. (Ed.). (2006b). Rondtrekkende dadergroepen: grensoverschrijdend beleid. Brussels: Politeia.

Dienst voor het Strafrechtelijk Beleid (2005). Jaarrapport 2005: georganiseerde criminaliteit in België 2003-2004. Brussels: Politeia.

Dienst voor het Strafrechtelijk Beleid (2007). Jaarrapport 2007: georganiseerde criminaliteit in België 2005-2006. Brussels: Politeia.

Dortans, H. (2007). Jahresbericht 2006: Eigentums- und Waffenkriminalität. Düsseldorf: LKA Nordrhein-Westfalen.

Dupuis, B. (2004). Rondtrekkende dadergroeperingen: de zon komt op in het oosten... Inforevue(Juni), 34-37. 
Huisman, S., and Van der Laan, F. (2005). Mobiel banditisme: ongestraft of afgestraft? Het Tijdschrift voor Politie(3), 20-24.

James, Z. (2007). Policing marginal spaces: controlling gypsies and travellers. Criminology and Criminal Justice, 7(4), 367-389.

Kleemans, E. (1996). Strategische misdaadanalyse en stedelijke criminaliteit. Enschede: Universiteit Twente.

Kruize, P. (2007). Analyse van geregistreerde helingzaken. In D. Van de Mheen and P. Gruter (Eds.), Helingpraktijken onder de loep: impressies van helingcircuits in Nederland (pp. 33-62). Den Haag: Boom Juridische uitgevers.

Lu, Y. (2003). Getting away with the stolen vehicle: an investigation of journey-after-crime. The Professional Geographer, 55(4), 422-433.

Lyman, M., and Potter, G. (1997). Organized crime. Upper Saddle River: Prentice Hall.

Marro, P. (2002). La délinquance itinérante en France en provenance des PECO. Paper presented at the International colloquium 'la politique et la gestion de flux migratoires dans la perspective de l'élargissement: sécurité nationale et stabilité sociale.

Nee, C., and Meenaghan, A. (2006). Expert decision making in burglars. British Journal of Criminology, 46(5), 935-949.

Palmer, E., Holmes, A., and Hollin, C. (2002). Investigating burglars' decisions: factors influencing target choice, method of entry, reasons for offending, repeat victimisation of a property and victim awareness. Security Journal, 15(1), 7-18.

Paulussen, L. (2007). Strategisch rapport sedentaire dadergroepen. s.l.: Federale Politie (protected document).

Ponsaers, P. (2004). Rondtrekkende dadergroepen: rationele Nederlandse criminologen en irrationele criminelen in Vlaanderen. Tijdschrift voor Criminologie, Jubileumuitgave, $15-23$.

Rattner, A., and Portnov, B. (2007). Distance decay function in criminal behaviour: a case of Israel. Annals of Regional Science, 41(3), 673-688.

Rengert, G., Piquero, A., and Jones, P. (1999). Distance decay reexamined. Criminology, $37(2), 427-446$.

Segaert, S. (2006). Criminele processen: heling en buit bij Roemeens rondtrekkende dadergroepen en communicatie bij rondtrekkende dadergroepen. In B. De Ruyver (Ed.), Rondtrekkende dadergroepen: grensoverschrijdend beleid (pp. 27-38). Brussel: Politeia.

Spapens, T., and Fijnaut, C. (2005). Criminaliteit en rechtshandhaving in de Euregio MaasRijn, 1: De problemen van transnationale (georganiseerde) criminaliteit en de grensoverschrijdende politiële, justitiële en bestuurlijke samenwerking. Antwerpen: Intersentia.

Stichting Maatschappij Veiligheid en Politie (2006). Tegenhouden van mobiel banditisme. Dordrecht: SMVP.

Sutton, M. (1998). Handling stolen goods and theft: a market reduction approach. London: Home office research and statistics directorate.

Tillyer, M., and Kennedy, D. (2008). Locating focused deterrence approaches within a situational crime prevention framework. Crime Prevention and Community Safety, $10(2), 75-84$.

Van Daele, S. (2008). Organised property crimes in Belgium: the case of the 'itinerant crime groups'. Global Crime, 9(3), 241-247.

Van Daele, S., Vander Beken, T., and De Ruyver, B. (2008). Rondtrekkende dadergroepen: een empirische toets. Panopticon, 29(4), 25-39. 
Van der Kemp, J., and Van Koppen, P. (2007). Finetuning geographical profiling. In R. Kocsis (Ed.), Criminal profiling: international perspectives in theory, practice, and research (pp. 347-364). Totowa: Humana.

Van der Laan, F., and Weenink, A. (2005). Eindrapportage van het project Polaris: Mobiel banditisme uit Polen en Litouwen. Zwolle: Korps Landelijke Politiediensten.

Van Koppen, P., and De Keijser, J. (1997). Desisting distance decay: On the aggregation of individual crime trips. Criminology, 35(3), 505-515.

Verwee, I., Ponsaers, P., and Enhus, E. (2007). Inbreken is mijn vak: textuur en praktijk van woninginbraak. Den Haag: Boom Juridische Uitgevers. 